\title{
Diana Maksimiuk
}

Instytut Pamięci Narodowej Oddział w Białymstoku

e-mail:dmax@gazeta.pl

ORCID: 0000-0002-7935-1879

DOI: $10.15290 / \mathrm{mhi} .2020 .19 .02 .17$

\section{Początki wymiaru sprawiedliwości na Białostocczyźnie w 1919 r. w świetle wileńskich archiwaliów}

\begin{abstract}
Abstrakt
Tworzenie wymiaru sprawiedliwości po odzyskaniu przez Polskę niepodległości w 1918 r. to zagadnienie niecieszące się zbyt dużym zainteresowaniem badaczy. Zasadniczy problem tkwi w braku źródeł historycznych dotyczących tej problematyki. Szczególnie jest to widoczne dla Ziem Wschodnich II Rzeczypospolitej, dla których materiały archiwalne uległy zniszczeniu w czasie II wojny światowej, a jeśli ocalały, to nierzadko dostęp do nich jest dziś dość utrudniony. Dzieje sądownictwa na Białostocczyźnie w okresie międzywojennym nie są dobrze znane właśnie z powodu braku źródeł. Dotychczasowe próby jego opisania opierały się wyłącznie na informacjach prasowych - głównie na lokalnej gazecie „Dziennik Białostocki” - oraz na aktach normatywnych publikowanych w dziennikach urzędowych wydawanych przez naczelne organy władzy państwowej. Sięgano również po literaturę wspomnieniową, ale i ta nie jest zbyt liczna. Okazuje się, że cenne materiały dotyczące początków polskiego wymiaru sprawiedliwości w Białymstoku z okresu marzec - czerwiec 1919 r. posiada w swoim zasobie Litewskie Centralne Archiwum Państwowe w Wilnie. Dzięki tym kilku dokumentom możemy poznać nie tylko niełatwy proces tworzenia miejscowego sądownictwa, ale także pierwsze miesiące jego działalności oraz z imienia i nazwiska ludzi, którzy w tym uczestniczyli. Z uwagi na fakt, iż archiwalia te nie są zbyt łatwo dostępne i nikt wcześniej do nich nie dotarł, część z nich (ukazujące działalność orzeczniczą w liczbach) opublikowano jako materiał dla przyszłych prac badawczych.
\end{abstract}




\section{Abstract \\ The beginnings of the justice in the Białystok region in 1919 in the light of Vilnius archives}

The creation of the justice system in Poland after it regained its independence in 1918 is an issue which does not attract too much interest from researchers. The main problem lies in the lack of historical sources on the subject. This is particularly evident with regard to the Eastern Lands of the Second Polish Republic as the archival materials concerting those lands were either destroyed during World War II, or if they were not, they are not easily accessible today. The judicial history of the Białystok region in the interwar period is not well known precisely because of the lack of sources. To date, the attempts to describe it have been based solely on press releases - mainly from the local newspaper "Dziennik Białostocki" - and on normative acts published in government gazettes issued by the state authorities. Memoirs have also been consulted, but there are not many of them either. As it turns out, the Lithuanian Central State Archives in Vilnius has valuable materials on the beginnings of Polish judiciary in Białystok from the period of March 1919 to June 1919. Thanks to these few documents, we can learn not only about the difficult process of creating the local judiciary, but also about the first months of its operation and the names of the people who participated in it. Due to the fact that these archives are not easily accessible and no one has reached them before, some of them (showing case-law figures) have been published as material for future research.

Słowa kluczowe: wymiar sprawiedliwości, Białystok, odzyskanie niepodległości Key words: justice, Białystok, regain independence

Białostocki historyk, Wiesław Wróbel, w publikacji jubileuszowej, która ukazała się na stulecie utworzenia Sądu Okręgowego w Białymstoku, napisał, iż „brakuje szczegółów na temat działań organizacyjnych sądu [w 1919 r.], a jedyne, fragmentaryczne informacje na ten temat możemy czerpać z lokalnej prasy" '. Stąd każdy materiał źródłowy z tego okresu dotyczący organizacji i funkcjonowania wymiaru sprawiedliwości na Białostocczyźnie po odzyskaniu przez Polskę niepodległości wydaje się być na wagę złota. Takie bezcenne dokumenty odnalezione zostały podczas kwerendy w Litewskim Centralnym Archiwum Państwowym w Wilnie w źródłach dotyczących działalności Sądu Okręgowego w Wilnie z lat 1919-1920.

O uwolnieniu Białegostoku spod okupacji niemieckiej można mówić dopiero w lutym 1919 r. Wówczas to do miasta, na mocy tzw. umowy białostockiej,

$1 \quad$ P. Fiedorczyk, K. Niewiński, W. Wróbel, Z dziejów Sądu Okręgowego w Białymstoku, Białystok 2019, s. 94. 
wkroczyło Wojsko Polskie przejmując po Niemcach władzę. Los okupowanej od 1915 r. Białostocczyzny, która nie wchodziła w skład Królestwa Polskiego i tym samym nie została objęta aktem 5 listopada 1916 r., dopiero się ważył. O zamierzeniach włączenia tego obszaru w granice odradzającego się państwa polskiego świadczy dekret z 28 listopada 1918 r. o wyborach do Sejmu Ustawodawczego RP, w myśl którego i na ziemiach byłego obwodu białostockiego miały być przeprowadzone wybory ${ }^{2}$. Nadto wymowne również było stworzenie urzędu Komisarza Rządu Polskiego na powiat białostocki, na który w listopadzie 1918 r. mianowany został przez szefa Rady Ministrów i Ministra Spraw Wewnętrznych Ignacy Mrozowski (choć zasadniczo akt nominacyjny dotyczył komisarzy „północnej części byłego Królestwa Polskiego") ${ }^{3}$. W lutym 1919 r. sprawa przyszłości Białegostoku i regionu nie została jednak jednoznacznie rozstrzygnięta. Na tamten moment cały obszar obwodu białostockiego znalazł się się pod polskim zarządem wojskowo-cywilnym, a lokalna ludność wezwana została przez komisarza Mrozowskiego do „bezwzględnego posłuszeństwa rozkazom władz wojskowych i cywilnych"4.

Pierwszym, polskim, wojskowym komendantem Białegostoku został płk Stanisław Dziewulski ${ }^{5}$. Miasto, jak i następnie zajmowane w wyniku „operacji wojsk polskich” obszary „Litwy i Białorusi” (od stycznia Polska znajdowała się w stanie wojny z bolszewicką Rosją), formalnie znalazły się w sferze działalności Zarządu Wojskowego Kresów Wschodnich (dalej: Zarząd Wojskowy) powołanego na mocy dekretu Naczelnika Państwa z 8 lutego 1919 r. ${ }^{6}$ Jak podała później lokalna

2 Kiedy zapadła uchwała o rozpisaniu wyborów w pow. białostockim w „Dzienniku Białostockim” napisano: „(..._) aczkolwiek akt o formalnem wcieleniu ziemi Białostockiej do państwa polskiego przez odnośne organy państwowe nie został wydany, to jednakże uchwała sejmu o rozpisaniu wyborów i ewentualne ich przeprowadzenie na miejscu już z góry położenie prawno-państwowe ziemi naszej przesądza”. Przed wyborami, 12 IV 1919.

3 Dział urzędowy, „Monitor Polski” 16 XI 1918. Zaznaczyć jednak trzeba, iż rozporządzenie Ministra Spraw Wewnętrznych z 14 listopada 1918 r. dla Komisarzy Rządu Polskiego dot. podziału administracyjnego i stanu prawnego powiatów północnej części byłego Królestwa Polskiego nie uwzględniało m.in. powiatu białostockiego. Zob. to rozporządzenie: „Monitor Polski” 16 XI 1918.

4 Rozporządzenia Komisarza Rzq̨du Polskiego, „Dziennik Urzędowy Komisarza Rządu Polskiego w Białymstoku” 1919, nr 1, s. 5; zob. też: Obowiązujące Postanowienia Władzy Wojskowej, „Dziennik Urzędowy Komisarza Rządu Polskiego w Białymstoku" 1919, nr 1, s. 1-2.

5 Pułownik Dziewulski do Białegostoku przybył wraz urzędnikami 17 lutego 1919 r. Zob. Białystok w odrodzonej Polsce. Na pamiątkę wejścia wojsk polskich do Białegostoku 19 lutego 1919 r., oprac. B. Samarski, M. Gajewski, Białystok 2014, s. 10; A. Miodowski, Białystok w okresie okupacji niemieckiej 1915-1919, [w:] 80 rocznica odzyskania niepodległości białostockie i łomżyńskie 1915-1919, red. A. Dobroński, A. Wap, Osowiec - Łomża 1998, s. 53.

6 Dekret Naczelnika Państwa z 8 lutego 1919 r. ustanawiający zarząd wojskowy na ziemiach Litwy i Białorusi, „Dziennik Urzędowy Generalnego Komisarza Cywilnego” 1919, nr 1, s. 1. W materiałach archiwalnych występuje też jako Zarząd Wojskowy Polskich Ziem Wschodnich. Szerzej zob. J. Gierowska-Kałłaur, Zarząd Cywilny Ziem Wschodnich (19 lutego 1919 - 9 września 1920), Warszawa 2003. Por. W. Tyszuk, Postawy społeczeństwa Białegostoku w okresie odzyskania niepodległości 1918-1920, [w:] Pierwsze dni niepodległości. Materiały z konferencji naukowej Białystok 14-16 marca 2018 r., red. N. Filinowicz i in., Białystok 2018, s. 296. 
prasa ziemia białostocka podporządkowana została „organom specjalnym dla zarządzania ziem kresowych stworzonym (Dep[atrament] Lit[ewsko-]Biał[oruski])"7. Do kompetencji organów Zarządu Wojskowego należał szeroki wachlarz zagadnień. Miał on zająć się m.in. organizacją „administracji kraju z podziałem terytorialnym na jednostki administracyjne i mianowaniem odnośnych organów administracji oraz dozór nad nimi”, a także „wymiaru sprawiedliwości w sprawach dotyczących ludności cywilnej za wyjątkiem spraw należących do sądu wojennego" tych zadań był powołany przy Zarządzenie Wojskowym Generalny Komisarz Cywilny, którym 19 lutego 1919 r. został szef Sekcji MSZ Dyrektor Departamentu Kresów Wschodnich ${ }^{9}$ Ludwik Kolankowski ${ }^{10}$. Na terenach wschodnich objętych operacjami reprezentowali go komisarze pełnomocni przy poszczególnych grupach wojsk (armiach) ${ }^{11}$. Z kolei w powiatach tych terenów tę "naczelną, państwową władzę administracyjną" reprezentowali komisarze powiatowi. Jedni i drudzy, jak i ich zastępcy oraz „inni, pozostający na służbie państwowej funkcjonariusze Zarządu Wojskowego" mianowani byli z ramienia Naczelnego Dowództwa WP przez Generalnego Komisarza Cywilnego i w związku z tym korzystali ,ze wszystkich praw, jakie przysługiwały oficerom w służbie w okręgu wojennym” oraz nosili „polowy uniform ustalony przez Naczelne Dowództwo WP ze złotymi szlifami”"12.

Białystok i powiat białostocki, obok powiatów wołkowyskiego, bielskiego, sokólskiego i grodzieńskiego znalazły się w sferze oddziaływania Macieja Jamontta, który został mianowany komisarzem pełnomocnym (okręgowym) przy dowództwie grupy wojsk gen. Stanisława Szeptyckiego. Jego zastępcą został Stanisław Kozakowski ${ }^{13}$. To w ich gestii znalazło się koordynowanie budowy struktur administracyjnych na powierzonym obszarze w myśl wydanego 22 lutego 1919 r. „Szematu Administracji Zarządu Kresów Wschodnich”, który w porozumieniu z Komitetem Obrony Kresów Wschodnich opracował Sztab Generalny WP. Z założenia miała to być administracja o charakterze przejściowym ściśle powiązana z operacjami militarnymi. Za najmniejszą jednostkę administracyjną

7 Memoriał Centralnego Polskiego Narodowego w Białymstoku, „Dziennik Białostocki”, 9 IV 1919.

8 CAW WBH w Warszawie, I.331.22.16, Rozkaz nr 1 gen. Stanisława Szeptyckiego, [1919], b.p.

9 Zwany też: Departamentem Ziem Wschodnich, Departamentem dla Spraw Polskich Ziem Wschodnich, Departamentem dla Ziem Wschodnich, Departamentem Litewsko-Białoruskim czy Departamentem Litewsko-Białoruskim Ziem Wschodnich.

10 Dekret Naczelnego Wodza z 19 lutego 1919 r. mianujący Generalnego Komisarza Cywilnego, „Dziennik Urzędowy Generalnego Komisarza Cywilnego” 1919, nr 1, s. 2.

11 W prasie pisano o „Komisarzu Państwowym przy armii operującej”, co później prostowano. Zob. Lustracja koni, „Dziennik Białostocki” 17 IV 1919; Sprostowanie, „Dziennik Białostocki”, 19 IV 1919.

12 CAW WBH w Warszawie, I.331.22.16, Rozkaz nr 1 gen. Stanisława Szeptyckiego, [1919], b.p.

13 Ibidem. 
przyjęto $\mathrm{w}$ dokumencie osadę lub wieś pod kierownictwem sołtysa. Kilka takich jednostek miało tworzyć gminę z wójtem na czele, $\mathrm{z}$ kolei kilkanaście gmin - powiat, którym zarządzał komisarz powiatowy. Największą jednostką w całej strukturze był okręg z komisarzem okręgowym ${ }^{14}$.

Zarządzanie powiatem białostockim przez komisarza Mrozowskiego zakończyło rozporządzenie Generalnego Komisarza Cywilnego z 1 marca 1919 r. Na jego mocy z dniem 4 marca tr. komisarzem powiatowym mianowano Augusta Cyfrowicza ${ }^{15}$. Cztery dni później komisarz Kolankowski wyznaczył też komisarza policji na powiat w osobie Władysława Józefa Dąbrowskiego. W tym dniu dodatkowo w domu własnym przy ul. Lipowej ${ }^{16}$ rozpoczął czynności sędzia pokoju na powiat białostocki Kazimierz Janowicz ${ }^{17}$. W samym mieście z kolei rozpoczął działalność Napoleon Cydzik jako komisarz rządowy miasta Białegosto$\mathrm{ku}^{18}$ oraz Stanisław Jankowski jako sędzia pokoju na miasto Białystok ${ }^{19}$. Niestety, o wszystkich tych urzędnikach nic lub bardzo niewiele wiadomo ${ }^{20}$.

$\mathrm{Z}$ odnalezionego w litewskim archiwum pisma sędziego Jankowskiego skierowanego do komisarza Kolankowskiego (miało charakter sprawozdawczy za okres od 20 marca do 10 kwietnia), wynika, iż tymczasowy lokal przy ul. Lipowej 51 dla sędziego pokoju został wynajęty w prywatnym domu ${ }^{21}$ za 3200 marek. Stało się tak, gdyż „władze wojskowe i cywilne - jak czytamy w piśmie - uchyliły

14 Por. W. Śleszyński, Budowa administracji polskiej na Polesiu w latach 1919-1920, [w:] Obszary zgody czy konfliktu? Kresy Pólnocno-Wschodnie II Rzeczypospolitej, red. W. Śleszyński, A. Włodarczyk, Białystok-Kraków 2014, s. 24

15 Obwieszczenie, „Dziennik Urzędowy Komisarza Rządu Polskiego w Białymstoku” 1919, nr 3, s. 2.

16 W prasie podano, iż przy ul. Lipowej 51. Sędziowie pokoju, „Dziennik Białostocki”, 9 IV 1919.

17 Wiadomości, „Dziennik Urzędowy Komisarza Rządu Polskiego w Białymstoku” 1919, nr 3, s. 3. Sędziowie pokoju pracowali w sądach najniższej instancji na terenie dawnego zaboru rosyjskiego do unifikacji ustroju sądownictwa, która nastąpiła z dniem 1 stycznia 1929 r. M. Materniak-Pawłowska, Zawód sędziego w Polsce w latach 1918-1939, „Czasopismo Prawno-Historyczne” 2011, t. LXIII, z. 1, s. 65 .

18 Jego pierwsze opublikowane rozporządzenie nosi datę 20 marca 1919 r. Rozporządzenie obowiązujace, „Dziennik Urzędowy Komisarza Rządu Polskiego na powiat Białostocki” 1919, nr 5, s. 6. Nie uzdrowiło to sytuacji w administracji. „W administracji w dalszym ciągu zamieszanie. (...) Zarówno w mieście jak i na wsi panuje chaos wywołany przez organy administracji. Koniecznym jest lepsze niż dzisiaj obsadzenie komisariatu miejskiego. Również komisarz powiatowy Cyfrowicz nie stanął na wysokości zadania. Zraża chłopów fatalnemi zarządzeniami podatkowymi. Obecnie wywołuje zatargi na temat odbierania chłopom koni dostarczonych im swego czasu przez Niemców". Archiwum Akt Nowych w Warszawie, Towarzystwo Straży Kresowej, 254, Pismo Wacława Vorbrodt-Brotowskiego do Wydziału Organizacyjnego Straży Kresowej w Warszawie, 11 IV 1919. k. 9; por. O niepodległa i granice. Raporty Straży Kresowej 1919-1920 Ziem Pólnocno-Wschodnich opisane, oprac. J. Gierowska-Kałłaur, Warszawa - Pułtusk 2011, s. 156.

19 Wiadomości, „Dziennik Urzędowy Komisarza Rządu Polskiego na powiat Białostocki” 1919, nr 5, s. 7.

20 Zob. M. Kietliński, Początki białostockiej niepodległości 1918-1920. Katalog wystawy, Białystok 2019.

21 Wygląda na to, że u sędziego Kazimierza Janowicza. 
się od wyznaczenia lokalu na Sąd"22. Pieniądze na jego funkcjonowanie zostały przekazane już w marcu ${ }^{23}$. Sędzia Jankowski wyznaczył do pracy kancelaryjnej dwóch pomocników sekretarza (został nim Aleksander Srzednicki) i jednego woźnego. $Z$ tym zespołem odbył 8 posiedzeń, na których rozpatrzył 70 spraw. Z liczby tej 34 zakończył (23 sprawy karne, 11 spraw cywilnych), a resztę odroczył. Na 12 kwietnia zakładał przyjęcie około 6 tys. „pozostałych spraw niemieckich”. W związku z ogromem pracy w piśmie do Komisarza Generalnego Cywilnego Zarządu Wojskowego zgłaszał zapotrzebowanie na dwóch woźnych, z których jeden miał mieć obowiązek doręczania wezwań i różnej korespondencji, drugi zaś - wyczytywania w trakcie posiedzeń sądowych stron i świadków oraz uporządkowywania lokalu sądowego. Uskarżał się też na brak komorników przy sądach, zwracając uwagę, że ich czynności spadły na policję miejską ${ }^{24}$. Jaka była odpowiedź komisarza nie wiadomo. W kolejnym jednak z odnalezionych pism, z 31 maja 1919 r., sędzia Jankowski informował, „iż wobec ciągle powiększającej się liczby spraw tak cywilnych jak i karnych a przeważnie więziennych, jak również wobec przyjęcia pozostałych różnych spraw za czasów władz niemieckich" zwiększył liczbę pracowników sądowych od kwietnia do dwóch kancelistów, z których jeden, władający językiem niemieckim, odszukiwał dokumenty na żądanie władz i osób zainteresowanych, drugi zaś zajmował się m.in. wypisywaniem wezwań, czy kopii zaocznych wyroków ${ }^{25}$. Nadto w obwieszczeniu komisarza Cyfrowicza przeczytamy o rozpoczęciu działalności z dniem 15 maja komornika sądowego (na powiat i miasto), którego siedziba mieściła się przy ul. Gimnazjalnej $5^{26}$. Z zachowanego materiału archiwalnego wynika, że funkcję kancelistki sędziego pokoju miasta Białegostoku pełniła małżonka sekretarza Kazimiera Srzednicka ${ }^{27}$. Wpływające sprawy cywilne dotyczyły głównie spraw mieszkaniowych ze względu na fakt ich braku i związanej z tym drożyzny nieruchomości ${ }^{28}$. Prezentowane poniżej dokumenty (nr 1-4) ukazują jak w liczbach

22 LCVA, f. 129, ap. 1, apsk. 7, Pismo sędziego Jankowskiego do Komisarza Generalnego Cywilnego Zarządu Wojskowego Kresów Wschodnich, 11 IV 1919, b.p. W prasie znajdziemy informacje, że urząd mieścił się przy ul. Fabrycznej 10. Oba sądy pokoju (na miasto i powiat) miały rozpocząć swoją działalność od 28 marca. Zob. Sędziowie pokoju, „Dziennik Białostocki”, 9 IV 1919.

23 LCVA, f. 129, ap. 1, apsk. 7, Pismo sekretarza Sądu Pokoju m. Białegostoku do Wydziału Sprawiedliwości Departamentu dla Spraw Polskich Ziem Wschodnich, 7 VII 1919, b.p.

24 LCVA, f. 129, ap. 1, apsk. 7, Pismo sędziego Jankowskiego do Komisarza Generalnego Cywilnego Zarządu Wojskowego Kresów Wschodnich, 11 IV 1919, b.p.

25 LCVA, f. 129, ap. 1, apsk. 7, Pismo sędziego Jankowskiego do Wydziału Prawnego Departamentu Litewsko-Białoruskiego Ziem Wschodnich, 31 V 1919, b.p.

26 Urząd został utworzony dekretem Departamentu dla Spraw Polskich Ziem Wschodnich z dnia 30 kwietnia 1919 r. Obwieszczenie, „Dziennik Urzędowy Komisarza Rządu Polskiego na powiat Białostocki" 1919, $\mathrm{nr}$ 9, s. 4.

27 LCVA, f. 129, ap. 1, apsk. 7, Pismo sędziego Jankowskiego do Wydziału Prawnego Departamentu dla Spraw Polskich Ziem Wschodnich, 4 VII 1919, b.p.

28 LCVA, f. 129, ap. 1, apsk. 7, Pismo sędziego Jankowskiego do Komisarza Generalnego Cywilnego Zarządu Wojskowego Kresów Wschodnich, 11 IV 1919, b.p. 
przedstawiała się działalność Sądu Pokoju miasta Białegostoku od początku działalności (od 12 marca) do końca czerwca 1919 r.

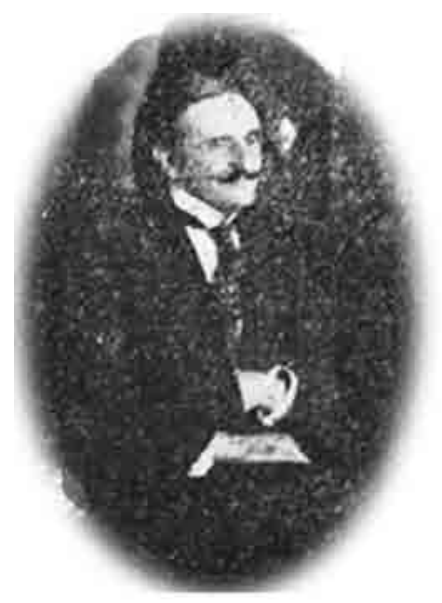

Stanisław Jankowski

Jak wyglądała z kolei działalność Sądu Pokoju w powiecie białostockim nie udało się ustalić na podstawie dostępnego materiału źródłowego. Wiadomo, że sędzia Janowicz pełnił swój urząd niespełna dwa miesiące, gdyż 24 kwietnia 1919 r. zmarł ${ }^{29}$. Trzy dni później „Dziennik Białostocki” informował o przybyciu do miasta wiceministra sprawiedliwości Eugeniusza Śmiarowskiego oraz sędziego Sądu Okręgowego w Warszawie, byłego adwokata przysięgłego w Białymstoku Tadeusza Straszewicza, w celu utworzenia Sądu Okręgowego ${ }^{30}$. Zanim do tego jednak doszło (1 sierpnia 1919 r. - już w nowych warunkach prawno-państwowych), komisarz Cyfrowicz na polecenie Departamentu Kresów Wschodnich z 29 kwietnia 1919 r. informował o utworzeniu w Białymstoku na cały powiat Sądów Pokoju dla spraw cywilnych i karnych, do kompetencji których należały powództwa na sumę do 5 tys. marek (lub 5 tys. rubli lub 2,5 tys. ost-rubli lub 7,5 tys. koron) ${ }^{31}$. Sądy te w gestii wspomnianego departamentu pozostały do końca czerwca 1919 r., z dniem bowiem 1 lipca 1919 r., jak informował Mieczysław Mickiewicz (szef Wydziału Sprawiedliwości Departamentu Kresów Wschodnich), wymiar sprawiedliwości w powiatach białostockim, bielskim

29 Zgon sędziego, „Dziennik Białostocki”, 25 IV 1919.

30 Sąd Okregowy, „Dziennik Białostocki”, 27 IV 1919. Por. P. Fiedorczyk, P. Kowalski, Sądownictwo powszechne na terenie województwa białostockiego w II RP, „Miscellanea Historico-Iuridica” 2012, t. XI, s. 280.

31 Obwieszczenie, „Dziennik Urzędowy Komisarza Rządu Polskiego na powiat białostocki” 1919, nr 9, s. 4. 
i sokólskim znalazł się w ewidencji ${ }^{32}$ Ministerstwa Sprawiedliwości ${ }^{33}$. Formalnie bowiem Białystok jak i powiat białostocki (wchodzący w skład utworzonego 2 sierpnia 1919 r. województwa białostockiego) znalazły się w granicach Polski - wyłączone zostały spod Zarządu Cywilnego Ziem Wschodnich ${ }^{34}$. I tak w nowych warunkach przystąpiono do uruchomienia Sądu Okręgowego w Białymstoku, którym pokierował wspomniany sędzia Straszewicz. Sędzia Jankowski został wiceprezesem tegoż sądu ${ }^{35}$.

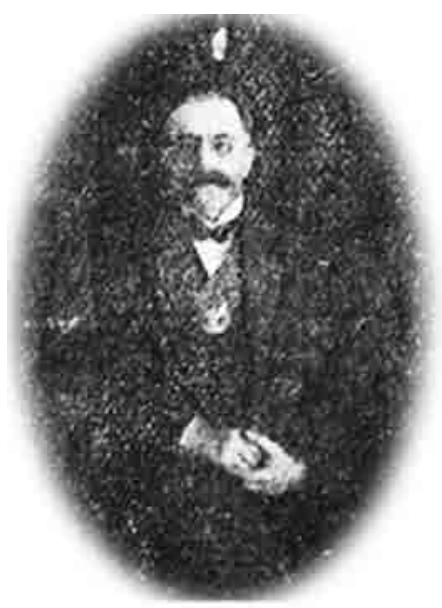

Tadeusz Straszewicz

Przez pryzmat wileńskich archiwaliów, które wytworzyła polska administracja cywilna między marcem a lipcem 1919 r., poznajemy kulisy powstawania wymiaru sprawiedliwości w Białymstoku po wkroczeniu do niego w lutym 1919 r. polskiego wojska. Początki białostockiego sądownictwa, w warunkach powojennych (I wojna światowa) oraz trwającego konfliktu z bolszewicką Rosją o kształt wschodniej granicy odrodzonej Rzeczypospolitej, były bardzo trudne. Problemy kadrowe i infrastrukturalne to główne bolączki, z którymi musiał zmierzyć się kierujący Sądem Pokoju w mieście sędzia Stanisław Jankowski. W przeciągu niespełna czterech miesięcy jego działalności orzeczniczej (do czasu utworzenia

32 W myśl okólnika ZCZW Nr 61 z dniem 30 czerwca 1919 r. wszelkie operacje kasowe i rachunkowości Sądu Okręgowego w Grodnie zostały zamknięte i z dniem 1 lipca tr. rozpoczęte na nowo. Zob. LCVA, f. 129, ap. 1, apsk. 7, Pismo Mieczysława Mickiewicza do prezesa Sądu Okręgowego w Grodnie, [1919], b.p.

33 LCVA, f. 129, ap. 1, apsk. 7, Pismo Mieczysława Mickiewicza do Sędziego Pokoju pow. bielskiego, 31 VII 1919, b.p.

34 W maju 1919 r. zastąpił Zarząd Wojskowy.

35 Wizerunki sędziów Jankowskiego i Straszewicza pochodzą z publikacji: Białystok Ilustrowany. Zeszyt pamiątkowy, red. A. Lubkiewicz, Białystok 1921, s. 48. 
w granicach Polski województwa białostockiego i powołania do życia Sądu Okręgowego w Białymstoku) do rozpatrzenia wpłynęły 844 sprawy karne i cywilne.

Cztery liczbowe sprawozdania $\mathrm{z}$ działalności Sądu Pokoju miasta Białegostoku zostały opublikowane in extenso. Przy edycji tych dokumentów (w celu odróżnienia od maszynopisu) zastosowano kursywę dla informacji, które $\mathrm{w}$ oryginale stanowią rękopis. W aneksie zdecydowano się na zamieszczenie kopii pisma sędziego Jankowskiego skierowanego do Wydziału Prawnego Departamentu spraw Polskich Ziem Wschodnich z 4 lipca 1919 r., na którym widnieją charakterystyczne pieczęcie: „Naczelne Dowództwo WP Zarząd Wojskowy Polskich Ziem Wschodnich Sędzia Pokoju m. Białegostoku" (okrągła i nagłówkowa) i „Departament dla spraw Polskich Ziem Wschodnich Wydział Sprawiedliwości” ( $\mathrm{z}$ datą wpływu pisma do tegoż departamentu: 17 VII 1919 r.).

\section{Dokumenty}

\section{nr 1}

1919 [kwiecień], Białystok - Sprawozdanie liczbowe z działalności Sądu Pokoju miasta Białegostoku za miesiąc marzec

Wykaz ruchu spraw w Sądzie Pokoju m[iasta] Białegostoku w ciągu Marca 1919 r.

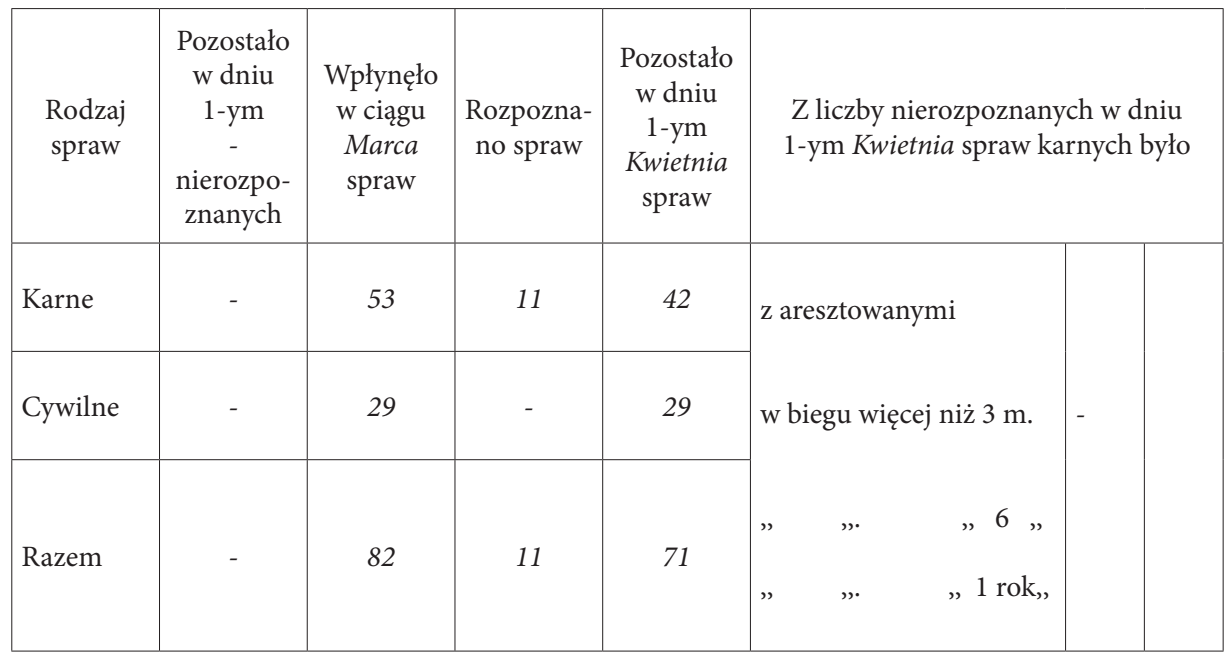

Sędzia Pokoju Jankowski ${ }^{a}$

Źródło: LCVA, f. 129, ap. 1, apsk. 7, k. 103, oryginał, mps, rkps.

a Poniżej pieczęć: „Sekretarz Sądu” z podpisem: „A. Srzednicki” oraz okragła pieczęć: „Naczelne Dowództwo WP Zarząd Wojskowy Polskich Ziem Wschodnich Sędzia Pokoju m. Białegostoku". W lewym dolnym rogu adnotacja: „Do Departamentu Litewsko-Białoruskiego Ziem Wschodnich Wydział Prawny d[nia] 16 maja 1919 r. Nr 76". 


\section{nr 2}

1919 [maj], Białystok - Sprawozdanie liczbowe z działalności Sądu Pokoju miasta Białegostoku za miesiąc kwiecień

Wykaz ruchu spraw w Sądzie Pokoju m[iasta] Białegostoku w ciągu Kwietnia 1919 r.

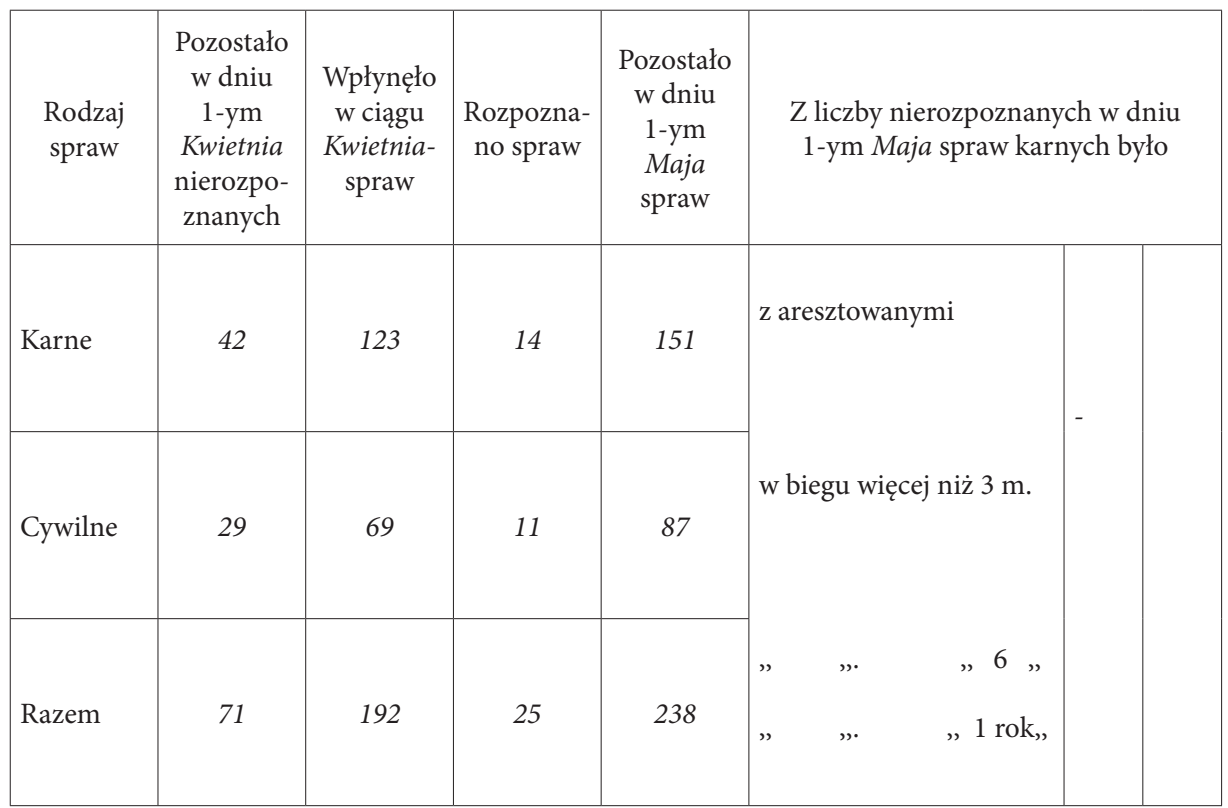

Sędzia Pokoju Jankowski

Źródło: LCVA, f. 129, ap. 1, apsk. 7, k. 104, oryginał, mps, rkps.

b Poniżej pieczęć: „Sekretarz Sądu” z podpisem: „A. Srzednicki” oraz okragła pieczęć: „Naczelne Dowództwo WP Zarząd Wojskowy Polskich Ziem Wschodnich Sędzia Pokoju m. Białegostoku". $W$ lewym dolnym rogu adnotacja: „Do Departamentu Litewsko-Białoruskiego Ziem Wschodnich Wydział Prawny d[nia] 16 maja 1919 r. Nr 77”. 


\section{nr 3}

1919 [czerwiec], Białystok - Sprawozdanie liczbowe z działalności Sądu Pokoju miasta Białegostoku za miesiąc maj

Wykaz ruchu spraw w Sądzie Pokoju m[iasta] Białegostoku w ciągu Maja 1919 r.

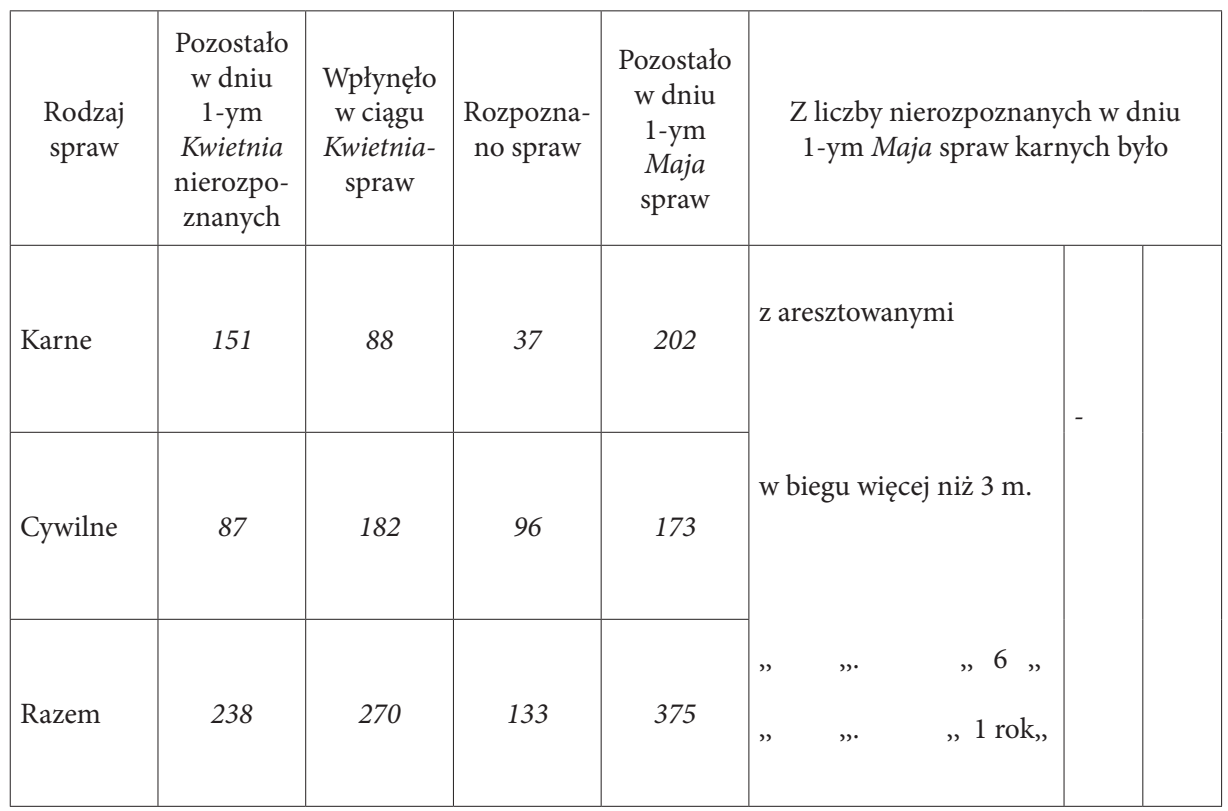

Sędzia Pokoju Jankowskic

Źródło: LCVA, f. 129, ap. 1, apsk. 7, k. 101, oryginał, rkps.

c Poniżej pieczęć: „Sekretarz Sądu” z podpisem: „A. Srzednicki” oraz okragła pieczęć: „Naczelne Dowództwo WP Zarząd Wojskowy Polskich Ziem Wschodnich Sędzia Pokoju m. Białegostoku”. W lewym dolnym rogu adnotacja: „Do Departamentu Litewsko-Białoruskiego Ziem Wschodnich Wydział Prawny 1 czerwca 1919 r. Nr 148”. 


\section{nr 4}

1919 [lipiec], Białystok - Sprawozdanie liczbowe z działalności Sądu Pokoju miasta Białegostoku za miesiąc czerwiec

Wykaz ruchu spraw w Sądzie Pokoju m[iasta] Białegostoku w ciągu Czerwca 1919 r. ${ }^{\mathrm{d}}$

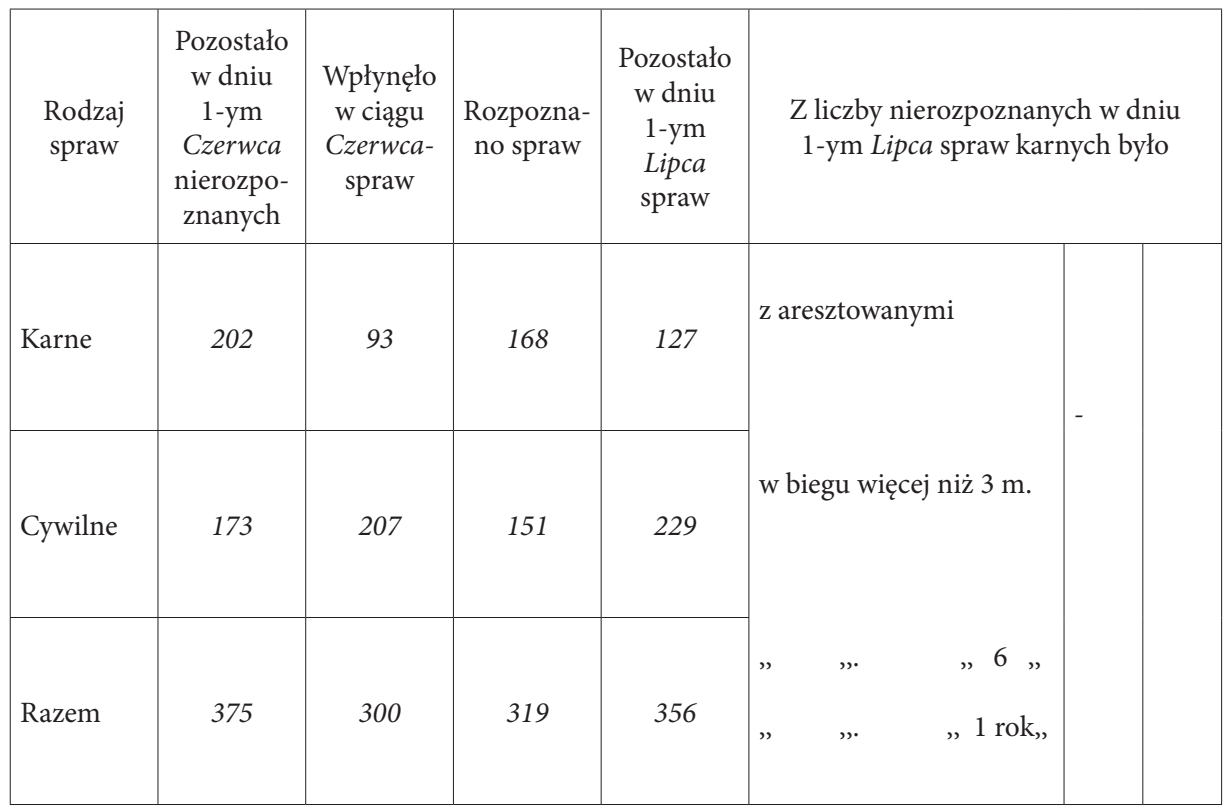

Sędzia Pokoju Jankowski ${ }^{e}$

Źródło: LCVA, f. 129, ap. 1, apsk. 7, k. 99, oryginał, mps, rkps.

d W prawym górnym rogu adnotacja Mieczysława Mickiewicza: „czy wykazy te rejestrowane są w jednym miejscu”. W lewym górnym rogu pieczęć: „Departament dla spraw Polskich Ziem Wschodnich Wydział Sprawiedliwości” z nieczytelnym numerem i data wplywu oraz adnotacją Mickiewicza: „do aktów".

e Poniżej pieczęć: „Sekretarz Sądu” z podpisem: „A. Srzednicki” oraz okragła pieczęć: „Naczelne Dowództwo WP Zarząd Wojskowy Polskich Ziem Wschodnich Sędzia Pokoju m. Białegostoku". W lewym dolnym rogu adnotacja: „Do Depart[amentu] Lit[ewsko] Białor[uskiego] Z[iem] W[schodnich] Wydział Prawny". 
Aneks

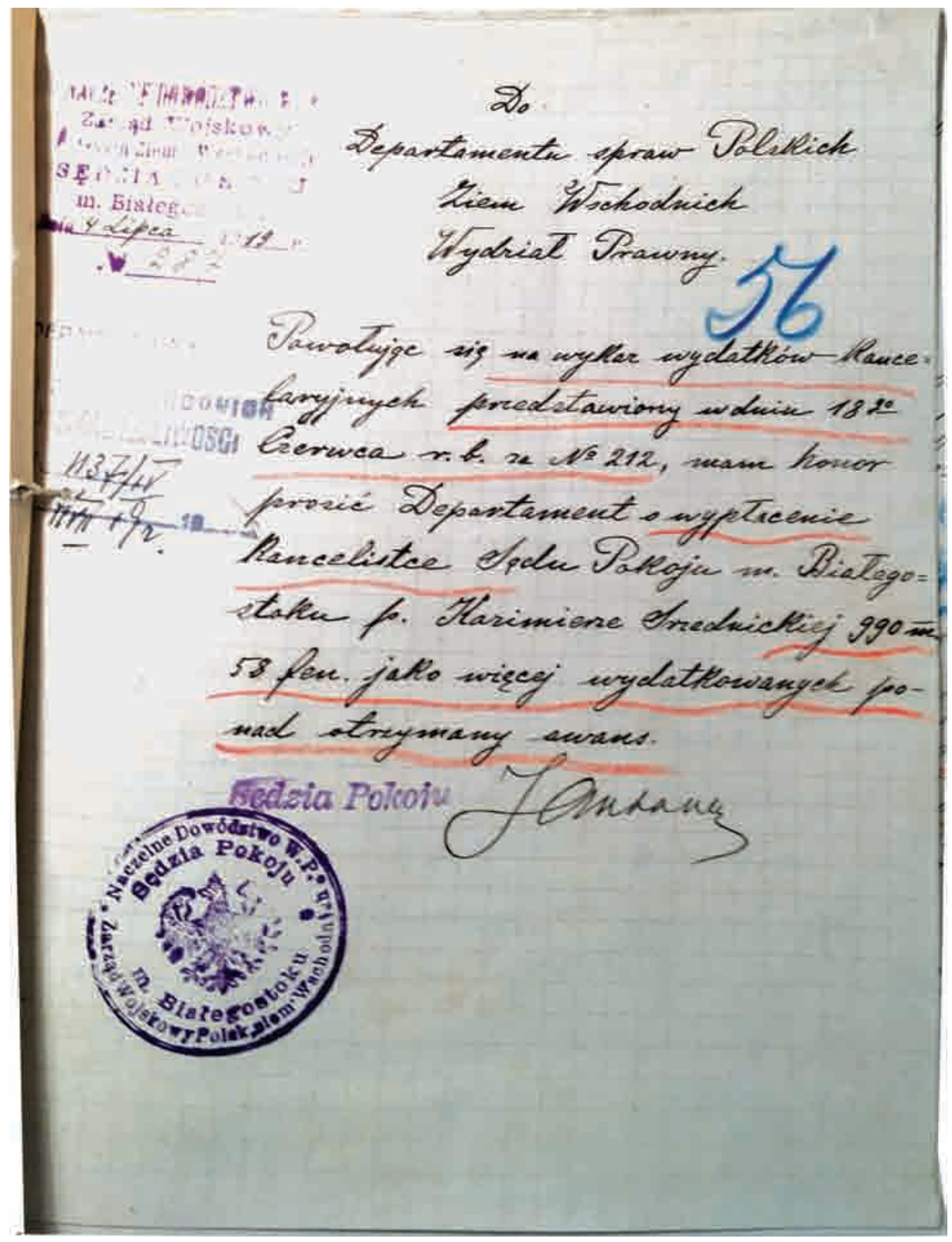

Źródło: LCVA, f. 129, ap. 1, apsk. 7, k. 56. 


\section{Bibliografia}

\section{Publikatory aktów prawnych}

„Dziennik Urzędowy Generalnego Komisarza Cywilnego” (1919)

„Dziennik Urzędowy Komisarza Rządu Polskiego na powiat białostocki” (1919)

„Dziennik Urzędowy Komisarza Rządu Polskiego w Białymstoku” (1919)

„Monitor Polski” (1918)

\section{Źródła archiwalne}

Centralne Archiwum Wojskowe Wojskowego Biura Historycznego im. gen. broni Kazimierza Sosnkowskiego w Warszawie, Dowództwa Okręgów Etapowych.

Litewskie Centralne Archiwum Państwowe w Wilnie, f. 129.

\section{Źródła drukowane i opracowania}

Białystok Ilustrowany. Zeszyt pamiątkowy, red. A. Lubkiewicz, Białystok 1921.

Białystok $w$ odrodzonej Polsce. Na pamiątkę wejścia wojsk polskich do Białegostoku 19 lutego 1919 r., oprac. B. Samarski, M. Gajewski, Białystok 2014.

Fiedorczyk P., Kowalski P., Sadownictwo powszechne na terenie województwa białostockiego w II RP, „Miscellanea Historico-Iuridica” 2012, t. XI.

Fiedorczyk P., Niewiński K., Wróbel W., Z dziejów Sądu Okręgowego w Białymstoku, Białystok 2019.

Gierowska-Kałłaur J., Zarząd Cywilny Ziem Wschodnich (19 lutego 1919 - 9 września 1920), Warszawa 2003.

Kietliński M., Początki białostockiej niepodległości 1918-1920. Katalog wystawy, Białystok 2019.

Materniak-Pawłowska M., Zawód sędziego w Polsce w latach 1918-1939, „Czasopismo Prawno-Historyczne” 2011, t. LXIII, z. 1.

Miodowski A., Białystok w okresie okupacji niemieckiej 1915-1919, [w:] 80 rocznica odzyskania niepodległości białostockie i łomżyńskie 1915-1919, red. A. Dobroński, A. Wap, Osowiec - Łomża 1998.

O niepodległa i granice. Raporty Straży Kresowej 1919-1920 Ziem Pólnocno-Wschodnich opisane, oprac. J. Gierowska-Kałłaur, Warszawa - Pułtusk 2011.

Śleszyński W., Budowa administracji polskiej na Polesiu w latach 1919-1920, [w:] Obszary zgody czy konfliktu? Kresy Północno-Wschodnie II Rzeczypospolitej, red. W. Śleszyński, A. Włodarczyk, Białystok - Kraków 2014.

Tyszuk W., Postawy społeczeństwa Białegostoku w okresie odzyskania niepodległości 1918-1920, [w:] Pierwsze dni niepodległości. Materiały z konferencji naukowej Białystok 14-16 marca 2018 r., red. N. Filinowicz i in., Białystok 2018.

\section{Prasa}

„Dziennik Białostocki” (1919) 


\section{STRESZCZENiE}

\section{Początki wymiaru sprawiedliwości na Białostocczyźnie w 1919 r. w świetle wileńskich archiwaliów}

W dotychczasowej historii Białostocczyzny początki polskiego wymiaru sprawiedliwości po odzyskaniu niepodległości w 1918 r. wiązano z datą 1 sierpnia 1919 r. Wówczas to powołano do życia Sąd Okręgowy w Białymstoku, a samo miasto dzień później formalnie znalazło się w granicach nowo utworzonego województwa białostockiego. Odnalezione w archiwum wileńskim dokumenty - w materiałach dotyczących funkcjonującego w latach 1919-1920 na obszarach zajętych przez Wojsko Polskie podczas konfliktu z bolszewicką Rosją Zarządu Cywilnego Ziem Wschodnich - ukazują, że polskie sądownictwo uruchomiono już w marcu 1919 r., niedługo po wkroczeniu tu polskich oddziałów, co miało miejsce 19 lutego 1919 r. Pod zarządem wojskowym utworzono w Białymstoku Sąd Pokoju, którym kierował Stanisław Jankowski. Jego prawą ręką, na stanowisku sekretarza sądu, został Aleksander Srzednicki. W trudnych warunkach po zakończeniu I wojny światowej i trwającego konfliktu polsko-bolszewickiego sędzia Jankowski musiał się zmierzyć nie tylko z działalnością orzeczniczą - zapewne nieprostą - ale również z problemami lokalowymi i kadrowymi. Do sądu tego w przeciągu niespełna czterech miesięcy funkcjonowania wpłynęły 844 sprawy karne i cywilne. Po tym okresie białostockie sądownictwo podlegające dotychczas pod Wydział Sprawiedliwości Departamentu dla spraw polskich Ziem Wschodnich przeszło pod nadzór Ministerstwa Sprawiedliwości. Sędzia Jankowski (jako wiceprezes) wraz z sędzią Tadeuszem Straszewiczem (prezes) pokierowali natomiast utworzonym Sądem Okręgowym w Białymstoku.

\section{SUMMARY}

\section{The beginnings of the justice in the Białystok region in 1919 in the light of Vilnius archives}

In the history of the Białystok region to date, the beginnings of the Polish judiciary after regaining independence in 1918 were connected with the date of 1 August 1919. It was then that the regional court in Białystok was established, and the city itself was formally included in the newly established Białystok Voivodship a day later. The documents found in the Vilnius archives - in materials concerning the Civil Administration of the Eastern Lands, which operated between 1919 and 1920 in the areas occupied by the Polish Army during the conflict with Bolshevik Russia show that the Polish judiciary was established as early as March 1919, shortly after the Polish troops entered the area, which took place on 19 February 1919. Under military administration, a peace court was established in Białystok, which was directed by Stanisław Jankowski. Aleksander Srzednicki became his right hand, as the court secretary. In the difficult circumstances following the end of World War I 
and the ongoing Polish-Bolshevik conflict, Judge Jankowski had to deal not only with judiciary activity - arguably not a simple one - but also with problems of premises and staffing. Within less than four months of its operation, 844 criminal and civil cases were brought before this court. After this period, the Białystok judiciary, which until then had been subordinated to the Division of Justice of the Department for Polish Affairs of the Eastern Lands, came under the supervision of the Ministry of Justice. Judge Jankowski (as vice-president), together with Judge Tadeusz Straszewicz (president), headed the established regional court in Białystok. 